\title{
Gametogenesis of Goussia gadi (Apicomplexa: Coccidia) in the swimbladder wall of haddock Melanogrammus aeglefinus
}

\author{
C. M. Morrison ${ }^{1}$, J. P. Leger ${ }^{2}$, C. A. Morrison ${ }^{1}$ \\ ${ }^{1}$ Department of Fisheries and Oceans, Biological Sciences Branch, Halifax, Nova Scotia, Canada B3J 2S7 \\ ${ }^{2}$ Anatomy Dept, Dalhousie University, Halifax, Nova Scotia, Canada B4H $4 \mathrm{H} 7$
}

\begin{abstract}
Developing microgamonts of Goussia gadi (Fiebiger, 1913), a parasite of haddock Melanogrammus aeglefinus, have numerous small, peripheral nuclei with dispersed chromatin, whereas there is one large eccentric nucleus in each macrogamont, containing a prominent nucleolus. There are lipid droplets and amylopectin granules in both types of gamont, and a prominent whorl of endoplasmic reticulum in the microgamont. A peripheral dark zone in each nucleus of the microgamont is incorporated into a biflagellate microgamete, which also contains microtubules and an elongate mitochondrion. Developing macrogamonts contain wall-forming bodies on the side of nucleus closest to the pellicle. The latter are found in an electron-dense layer external to the pellicle of mature macrogametes, and microgametes are found in a cleft in this layer.
\end{abstract}

KEY WORDS: Coccidia Gametogenesis - Goussia gadi Haddock - Macrogamete - Macrogamont . Melanogrammus aeglefinus · Microgamete $\cdot$ Microgamont $\cdot$ Swimbladder

\section{INTRODUCTION}

Goussia gadi is a coccidian parasite infecting the swimbladder of cod Gadus morhua, haddock Melanogrammus aeglefinus, pollock Pollachius virens and fourbeard rockling Enchelyopus cimbrius (Fiebiger 1913, Odense \& Logan 1976, Dykova \& Lom 1983, Upton et al. 1984, Morrison et al. 1986). The pathology and merogony have been described using light and electron microscopy (Morrison et al. 1993). In the present study the gametogony of this parasite is described.

\section{MATERIALS AND METHODS}

These have been described in Morrison et al. (1993). Briefly, haddock from the Scotian Banks were examined for infection by slitting the swimbladder ventrally, and specimens with yellow exudate were fixed in $1 \%$ glutaraldehyde and $4 \%$ formaldehyde in phosphate buffer (McDowell 1978). Specimens were processed for paraffin embedding, for embedding in JB4 resin for light microscopy and $\mathrm{TAAB}$ resin for transmission electron microscopy.

\section{RESULTS}

Developing microgamonts are found in parasitophorous vacuoles surrounded by a thin rim of host cytoplasm, and contain numerous small peripheral nuclei 1 to $2 \mu \mathrm{m}$ in diameter that contain several small aggregations of chromatin (Fig. 1). Two centrioles appear on the external surface of each nucleus (Fig. 2). Most of these nuclei are next to the pellicle or large vesicles which form adjacent to the pellicle, but some are next to fissures which extend into the interior of the gamont (Figs. 3 \& 4). There is a prominent whorl of smooth endoplasmic reticulum in the cytoplasm, as well as Golgi bodies, mitochondria, amylopectin granules and lipid droplets.

The 2 centrioles form the basal bodies of flagella at the surface of the microgamont. Initially the flagella 
are separate from the nuclei, which have closely associated mitochondria (Fig. 5). A peripheral protrusion of each nucleus that is darker than the rest of the nucleus forms on the surface of the microgamont (Fig. 6), and the flagella are found at the apex of the protrusion (Fig 7). The dark part of the nucleus and an accompanying mitochondrion become elongate (Figs. 8 \& 9). The developing microgamete is joined to the residual mass by a stalk surrounded by a dense ring, and part of the nucleus is left in the residuum. The mitochondrion and a group of microtubules are closely associated with the nucleus (Fig. 10). In transverse section, the mitochondrion can be seen in a depression on one side of the nucleus, surrounded by about 6 microtubules. In some sections of microgametes microtubules alone are present next to the nucleus (Fig. 11). Two flagella are associated with each microgamete (Figs. 12 \& 13).

Developing macrogamonts are found in host cells in large vacuoles lined with a single membrane, giving a 'honeycomb' appearance to the tissue (Fig. 14). They are ovoid to round, and have a large nucleus with a prominent nucleolus (Figs, 14 \& 15). Young macrogamonts have an irregular outline with numerous indentations. There are vesicles of smooth and rough endoplasmic reticulum in the cytoplasm, and peripheral mitochondria and amylopectin granules.

Lipid droplets surrounded by a ring of amylopectin granules appear to one side of the nucleus in larger macrogamonts (Fig. 16). Narrow vesicles of smooth endoplasmic reticulum partially surround the lipid droplets (Fig. 17). In more mature macrogamonts membrane-bound wall-forming bodies form on the side of the nucleus opposite the lipid droplets (Fig. 18). The nucleus is eccentric, and closer to the pellicle on this side. There are relatively homogeneous regions devoid of organelles in the cytoplasm. The pellicle is surrounded by a wide layer of fine filaments. The wallforming bodies contain fibrous material oriented in various directions, giving a 'spongy' appearance, and are surrounded by an electron-transparent halo. They are associated with vesicles of smooth endoplasmic reticulum and Golgi bodies (Fig. 19). The pellicle is trilayered, and a micropore was occasionally seen (Fig. 20).

In more advanced macrogamonts the inner membrane of the pellicle is fragmented, and there is a layer of electron-dense material limited by an undulating membrane external to the pellicle. This layer contains wall-forming bodies, and in some places there is an- other outer membrane. The wall-forming bodies are similar in appearance to those inside the macrogamont when they are small, and are found close to them (Fig. 21). In some macrogamonts, membranes extend from the wall-forming bodies in the cytoplasm to the pellicle.

Mature macrogametes are $18.7 \mu \mathrm{m}$ in diameter (average of 9 measurements from $0.5 \mu \mathrm{m}$ semi-thin sections; range 17.1 to $22.8 \mu \mathrm{m}$ ), excluding the electrondense layer, which is transparent in most resin sections prepared for light microscopy. There are large, dark, homogeneous wall-forming bodies in this layer, and there are no wall-forming bodies within the cytoplasm (Figs, 22 \& 23). Some macrogametes are still in parasitophorous vacuoles, but they are often found loose between debris of host cells, apparently protected by the outer layer of fine filaments (Figs. 18, $22 \& 23$ ). The wall-forming bodies are often in close contact with the pellicle of the macrogamete, and there are small dense vesicles around them, in the peripheral cytoplasm of the macrogamete and in pinocytotic vesicles (Fig. 24).

Microgametes are found around the macrogamete, especially on the side where the nucleus comes closest to the pellicle. They occur in a cleft formed by the membrane limiting the electron-dense layer (Fig. 25). There may be another membrane surrounding these microgametes. In some macrogametes there are periodic electron-dense formations on the external surface of the nucleus near the cleft (Fig. 26), and chromatinlike material is evident at the base of the cleft in some micrographs (Fig. 27)

\section{DISCUSSION}

Unlike most coccidia (Chobotar \& Scholtyseck 1982, Jastrzebski 1989, Lom et al. 1991), all developmental stages of Goussia gadi are covered by a 3-layered pellicle until wall-forming bodies start to appear. The gamonts are initially in host cell vacuoles, but the later stages are often free, so the pellicle may help to protect the parasite.

Early developmental stages of microgamonts are difficult to distinguish from meronts but, as described by Ferguson et al. (1977a), in Eimeria brunetti the nuclei in the meronts of $G$. gadi have a prominent nucleolus and do not decrease in size as they divide, whereas those of microgamonts have a patchy distribution of chromatin and become smaller as they divide. The de-

Abbreviations used in the figures. $\mathrm{AG}=$ amylopectin granule; $\mathrm{BB}=$ basal bodies; $\mathrm{Ce}=$ centriole; $\mathrm{Ch}=$ chromatin-like material; $\mathrm{Cl}=$ cleft $\mathrm{DC}=$ dense collar; $\mathrm{DV}=$ dense vesicles; $\mathrm{ER}=$ endoplasmic reticulum; $\mathrm{FF}=$ fine filamentous layer; $\mathrm{Fi}=$ fissure; $\mathrm{Fl}=$ flagellum; $\mathrm{GB}=$ Golgi body; $\mathrm{HC}=$ host cell cytoplasm; $\mathrm{HR}=$ homogeneous region; $\mathrm{LD}=$ lipid droplet; $\mathrm{Mern}=$ : membrane; $\mathrm{Mg}=$ microgamete; $\mathrm{Mi}=$ mitochondrion; $\mathrm{Mic}=$ microtubule; $\mathrm{Mp}=$ micropore $; \mathrm{Nu}=$ nucleus; $\mathrm{PF}=$ periodic formation; $\mathrm{PiV}=$ pinocytotic vesicle; $\mathrm{PV}=$ parasitophorous vacuole $\mathrm{V}=$ vesicle $; \mathrm{WB}=$ wall-forming body 


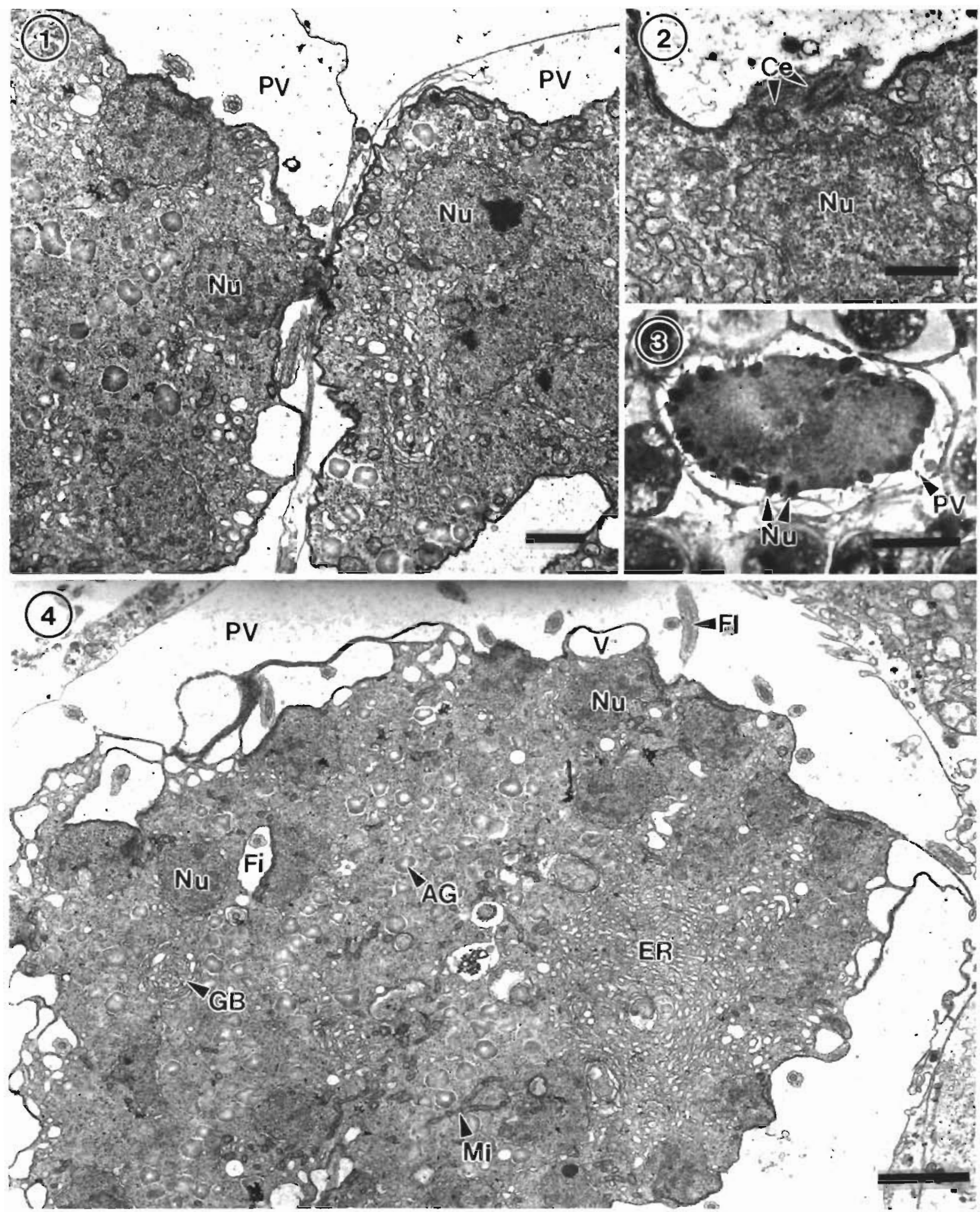

Figs. 1 to 4. Goussia gadi parasitizing Melanogrammus aeglefinus. Fig.1. Developing microgamont with small nuclei containing dispersed chromatin, and meront having larger nuclei with chromatin concentrated in distinct nucleoli distributed throughout the cytoplasm, in vacuoles limited by a single membrane. $\Upsilon E M$; scale bar $=1 \mu \mathrm{m}$. Fig. 2 . Two centrioles distal to the nucleus of a developing microgamont. TEM; scale bar $=0.5 \mu \mathrm{m}$. Fig. 3. Developing microgamont with nuclei situated peripherally. JB4, methylene blue/basic fuchsin; scale bar $=15 \mu \mathrm{m}$. Fig. 4. Developing microgamont nuclei and large vesicles near the pellicle, and fissures extending interiorly from the pellicle. There is a prominent whorl of endoplasmic reticulum, Golgi bodies, mitochondria and amylopectin granules. TEM; scale bar $=2.5 \mu \mathrm{m}$ 

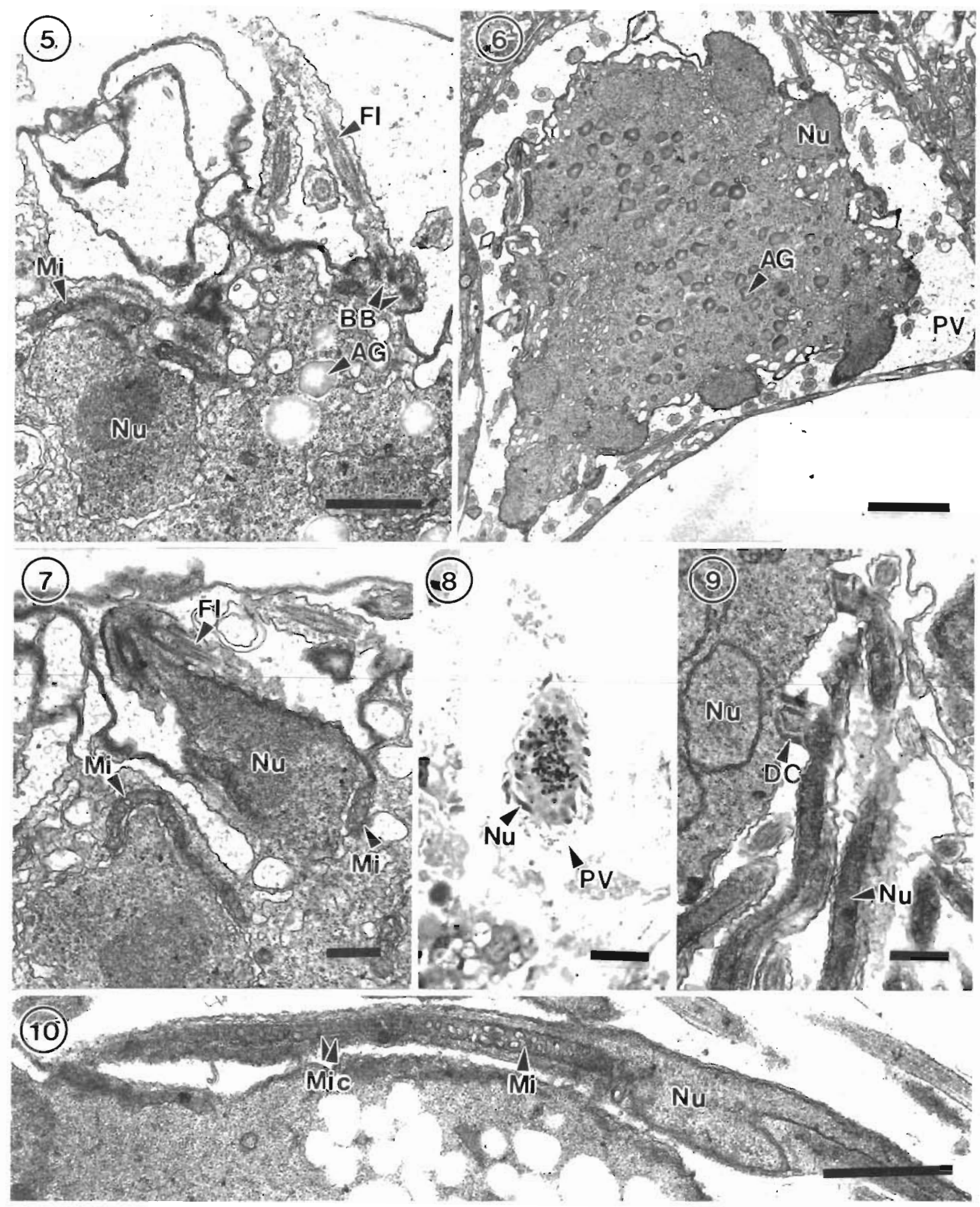

Figs. 5 to 10 . Goussia gadi parasitizing Melanogrammus aeglefinus. Fig. 5 . Mitochondra closely associated with the external surface of the nucleus at the periphery of a microgamont. Two flagella, with basa? bodies close together, extend from the surface of the microgamont. TEM; scale bar $=1 \mu \mathrm{m}$. Fig. 6. Microgamont in host cell vacuole A dark peripheral portion of each nucleus extends from the microgamont. TEM; scale bar $=2.5 \mu \mathrm{m}$. Fig. 7 . Two flagella extending from the apex of the dark peripheral extension of the nucleus of a developing microgamete. TEM; scale bar $=0.5 \mu \mathrm{m}$. Fig. 8 . Elongate nuclei of microgametes extend from the microgamont. $0.5 \mu \mathrm{m}$ section of TEM sample; scale bar $=10 \mu \mathrm{m}$. Fig. 9. Microgametes are attached to the residuun of a microgamont by stalks with electron-dense collars. TEM; scale bar $=0 . \overline{5 \mu \mathrm{m}}$. Fig. 10. Adjacent elongate mitochondria, nucleus and microtubules of a microgamete. TEM; scale bar $=1 \mu \mathrm{m}$ 


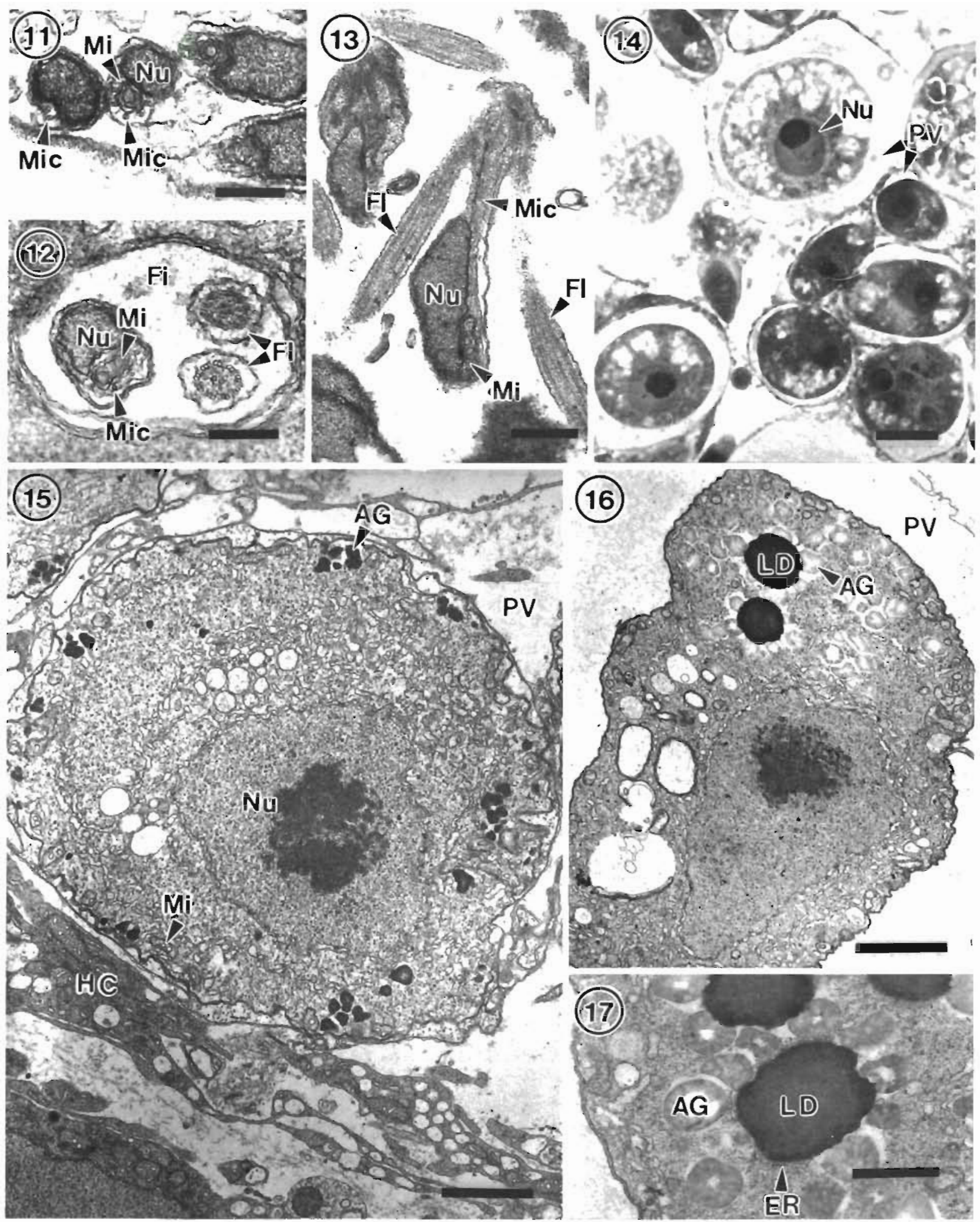

Figs. 11 to 17. Goussia gadi parasitizing Melanogrammus aeglefinus Fig. 11. Cross-sections of microgametes, showing the mitochondrion in a depression to one side of the nucleus, with surrounding microtubules in one cross-section only microtubules can be seen. TEM; scale bar $=0.25 \mu \mathrm{m}$. Fig 12 Cross-sectıon of microgamete with 2 flagella in a microgamont fissure. TEM. scale bar $=0.25 \mu \mathrm{m}$. Fig. 13. Two flagella and a group of microtubules closely associated with the nucleus at the apex of a microgamete $\mathrm{TEM}_{i}$ scale $\mathrm{bar}=0.5 \mu \mathrm{m}$. Fig. 14. Developing maciogamonts in host cell vacuoles JB4, methylene blue/basic fuschin, scale bar $=$ $10 \mu \mathrm{m}$. Fig. 15. Amylopectin granules and mitochondria in the peripheral cytoplasm of a developing macrogamont in a host cell vacuole. TEM; scale bar $=1.5 \mu \mathrm{m}$. Fig. 16 Lipid droplets surrounded by amylopectin granules in the cytoplasm of a developıng macrogamont. TEM; scale bar $=2 \mu \mathrm{m}$. Fig. 17 . Narrow vesıcles of smooth endoplasmic reticulum surrounding the lıpıd droplet in a developing macrogamont TEM, scale bas $=1 \mu \mathrm{m}$ 


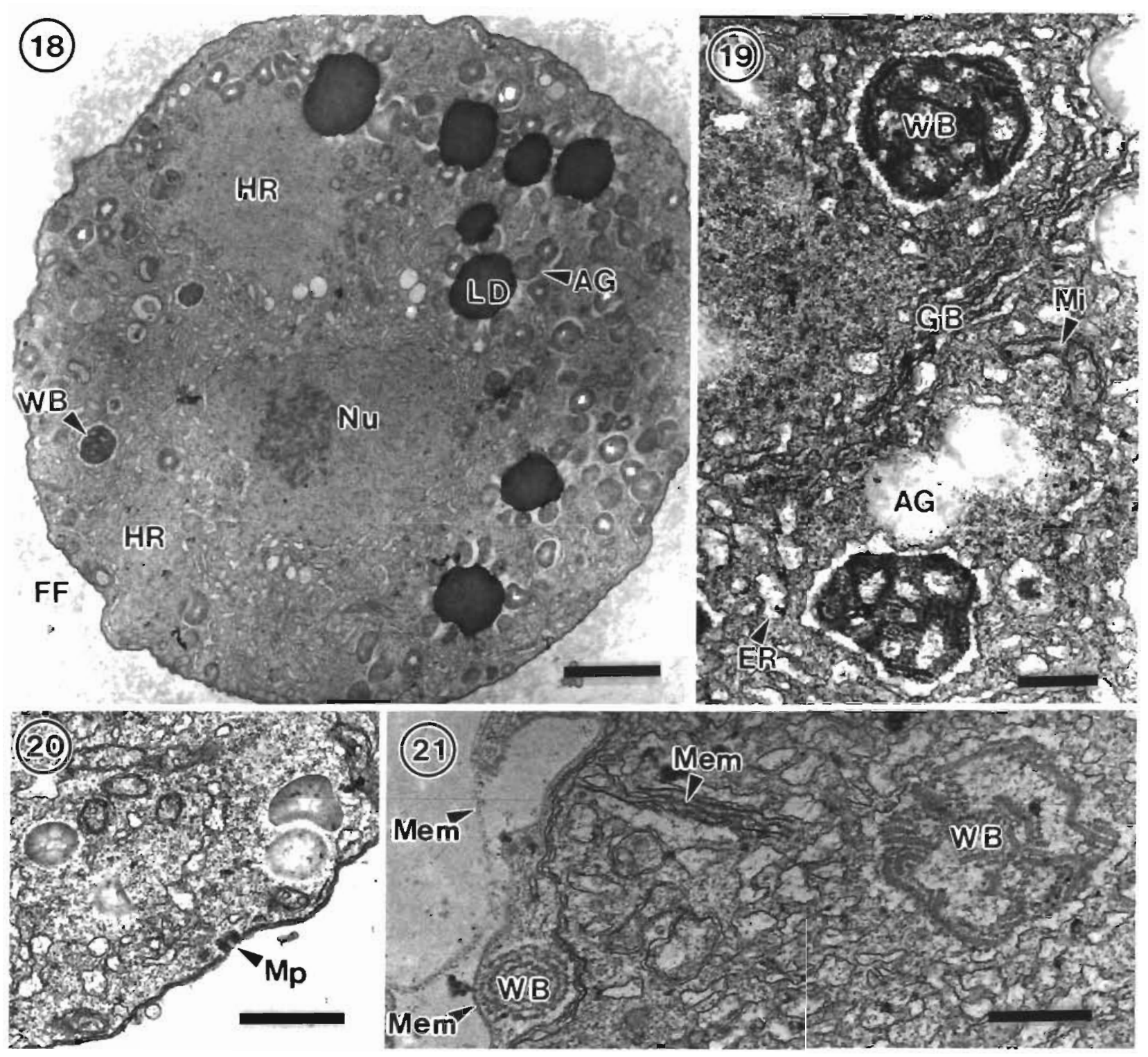

Figs. 18 to 21 Goussia gadi parasitizing Melanogrammus aeglefinus. Fig. 18. Macrogamont with developing wall-forming bodies, surrounded by a layer of fine filaments. TEM; scale bar $=2 \mu \mathrm{m}$. Fig. 19. Wall-forming bodies of a developing macrogamont, surrounded by vesicles of smooth endoplasmic reticulum, closely associated with a Golgi body. TEM; scale bar $=0.5 \mu \mathrm{m}$. Fig. 20 . Micropore in the pellicle of a macrogamont. TEM; scale bar $=1 \mu \mathrm{m}$. Fig. 21 Wall-forming body in the cytoplasm of a developing macrogamont and in an electron-dense membrane-bound layer external to the pellicle There is a group of parallel membranes in the cytoplissm. TEM; scale bar $=0.5 \mu \mathrm{m}$

velopment and structure of the microgamete are similar to those described in other piscine coccidia (Ferguson et al. 1974, Paterson \& Desser 1981a, Hawkins et al. 1983b, Desser \& Li 1984, Steinhagen et al. 1990 . Steinhagen 1991). Fiebiger (1913) was unable to detect flagella in the microgametes of $G$. gadi using light microscopy, but flagella are clearly visible in electron micrographs. These microgametes develop at the periphery of the microgamont and next to fissures extending into the interior, as described in other coc- cidia which produce many microgametes (Chobotar \& Scholtyseck 1982).

As in Goussia carpelli (Steinhagen 1991), Goussia iroquoina (Paterson \& Desser 1981b), and Calyptospora funduli (Hawkins et al. 1983a) there are few filaments or vesicles in the parasitophorous vacuole surrounding the young macrogamont. Hawkins et al. (1983a) suggested that uptake of nutrients may occur through surface invaginations as well as micropores, since the surface of the young macrogamont is undulating; the 

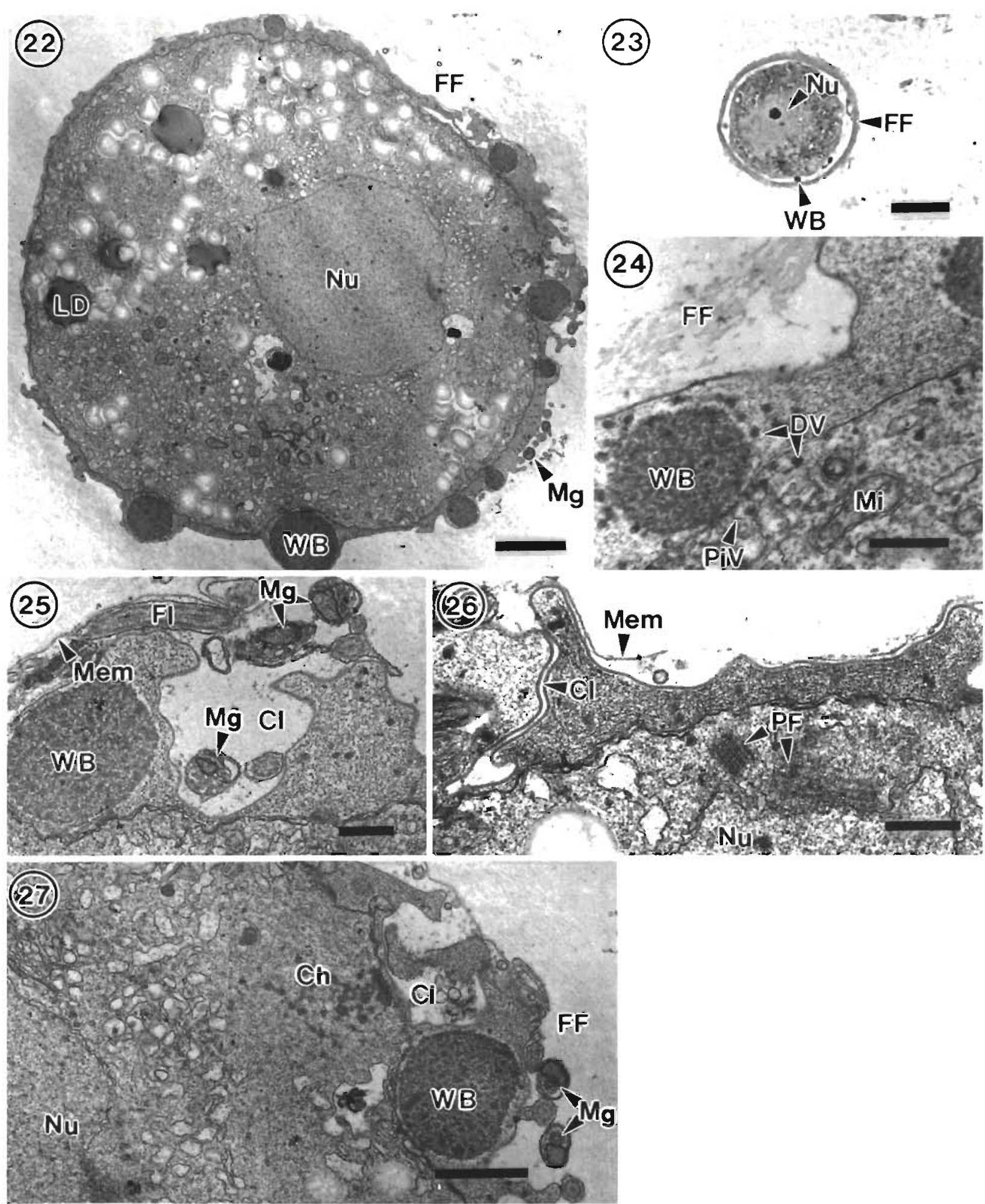

Figs. 22 to 27. Goussia gadi parasitizing Melanogrammus aeglefinus. Fig. 22. Macrogamete with homogeneous, electron-dense wall-forming bodies outside the pellicle. TEM; scale bar $=2.5 \mu \mathrm{m}$. Fig. 23 . Macrogamete surrounded by a fine filamentous layer $0.5 \mu \mathrm{m}$ section of EM sample stained with toluidine blue; scale bar $=10 \mu \mathrm{m}$. Fig. 24. Small dense vesicles around a wall-forming body, in a pinocytotic vesicle and in the peripheral cytoplasm of the macrogamete. TEM; scale bar $=0.5 \mu \mathrm{m}$. Fig. 25 . Microgametes in a cleft extending to the pellicle of the macrogamete. TEM; scale bar $=0.5 \mu \mathrm{m}$. Fig. 26. Periodic formations on the outer face of the nucleus, near a cleft. TEM; scale bar $=0.5 \mu \mathrm{m}$. Fig. 27 . Chromatin-like material near the base of a cleft. TEM; 
lining of the parasitophorous vacuole could also be involved in the early stages.

The round osmiophilic droplets found in the gamonts of Goussia gadi are assumed to be lipid because they are osmiophilic, and also because Fiebiger (1913) reported that highly refractive granules and droplets in younger stages and sporocysts stained with sudan black, scarlet red and osmic acid. These droplets also have the amorphous appearance typical of lipid, are not membrane-bound, and are often partially surrounded by smooth endoplasmic reticulum, like the lipid droplets found in host cells. Fiebiger reported large, refractile fat droplets, and small granules about $0.8 \mu \mathrm{m}$ in diameter which stain yellow with iodine in macrogamonts. The latter are probably amylopectin granules, which are about 0.4 to $0.7 \mu \mathrm{m}$ in diameter in the micrographs in the present account. Lipid droplets surrounded by a circle of amylopectin granules have also been described in the macrogamont of Eimeria vanasi (Kim \& Paperna 1992).

No bodies similar in appearance to the 'wall-forming bodies' described in coccidia in terrestrial vertebrates and in some piscine coccidia, such as Eimeria vanasi (Kim \& Paperna 1992) and Eimeria clupearum (Morrison \& Hawkins 1984), were found in Goussia gadi. The wall-forming bodies in G. gadi are similar in appearance to the 'wall-forming bodies' of coccidia parasitizing terrestrial vertebrates (Scholtyseck 1973, Chobotar \& Scholtyseck 1982). In the latter, wall-forming bodies form a thick protective oocyst wall external to the zygote, which may be surrounded by membranes derived from the cell membrane of the zygote (Ferguson et al. 1977b). The wall of the parasitophorous vacuole is external to these membranes. Wall-forming bodies are not usually involved in the production of an oocyst wall in piscine coccidia, which require only a thin layer for protection in an aqueous environment (Dykova \& Lom 1981). In the macrogamonts of G. gadi material seems to be transported from the wall-forming bodies in the macrogamont to form new bodies external to the pellicle before the sporocyst wall starts to form. The electron-dense, membrane-bound layer containing these bodies external to the pellicle is described by Fiebiger (1913) as a gelatinous, homogeneous zone produced by the parasite. The origin of the layer of fine filaments surrounding the macrogamont, which seems to have a protective function, is unknown.

Apparently microgametes actively move towards the macrogamete for fertilization, since several were found external to the electron-dense layer, close to the eccentric nucleus of the macrogamete. The microgametes apparently pass through the cleft in this layer to fertilize the macrogamete. Intact microgametes have been reported in the cytoplasm of the macrogamete of
Goussia iroquoina (Paterson \& Desser 1984), but in $G$. gadi only chromatin-like material, which could be microgamete nucleoplasm, was seen in the macrogamete. The diameter obtained for the mature macrogamete is slightly smaller than that recorded by Fiebiger (1913), who found a diameter $20 \mu \mathrm{m}$, excluding the electron-dense layer.

Acknowledgements. We thank Dr G. McClelland for his careful review of the manuscript, and helpful comments, and $\mathrm{Mr}$ Ken Freeman for reading and checking the manuscript.

\section{LITERATURE CITED}

Chobotar, B., Scholtyseck, E. (1982). Ultrastructure. In: Long, P. L. (ed.) The biology of the coccidia. Edward Arnold, London, p. 101-166

Desser, S. S., Li, L. (1984). Ultrastructural abservations on the sexual stages and oocyst formation in Eimeria laureleus (Protozoa, Coccidia) of perch, Perca flavescens, from Lake Sasjewun, Ontario. Z. Parasitenkd. 70: 153-164

Dykova, 1., Lom, J. (1981). Fish coccidia: critical notes on life cycles, classification and pathogenicity. J Fish Dis. 4: 487-505

Dykova, I., Lom, J. (1983). Fish coccidia: an annotated list of described species. Folia parasitol. (Praha) 30: 193 -208

Ferguson, D. J. P., Birch-Andersen, A., Hutchison, W. M., Chr. Siim, J. (1977a). Ultrastructural studies on the endogenous development of Eimeria brunetti. II. Microgametogony and the microgamete. Acta path. microbiol. Scand. Sect. B 85: $67-77$

Ferguson, D. J. P., Birch-Andersen, A., Hutchison, W.M., Chr Siim, J. (1977b). Ultrastructural studies on the endogenous development of Eimeria brunetti. IV. Formation and structure of the oocyst wall. Acta pathol microbiol. Scand. Sect. B 85: 201-211

Ferguson, D. J. P., Hutchison, W. M., Dunachie, J. F., Chr. Sim, J. (1974). Ultrastructural study of early stages of asexual multiplication and microgametogony of Toxoplasma gondii in the small intestine of the cat. Acta pathol. microbiol. Scand. Sect. B 82:167-181

Fiebiger, J. (1913). Studien über die Schwimmblasencoccidien der Gadusarten (Eimeria gadi n.sp.). Arch Protistenkd. 31: 95-137

Hawkins, W. E., Solangi, M. A., Overstreet, R. M. (1983a) Ultrastructure of the macrogamont of Eimeria funduli, a coccidium parasitizing killifishes. J. Fish Dis. 6: 33-43

Hawkins, W. E., Solangi, M. A., Overstreet, R. M. (1983b). Ultrastructure of the microgamont and microgamete of Eimeria funduli, a coccidium parasitizing killifishes. J Fish Dis. 6: 45-57

Jastrzebski, M. (1989). Ultrastructural study of the development of Goussia aculeati, a coccidium parasitizing the three-spined stickleback Gasterosteus aculeatus. Dis aquat. Org. 6: 45-53

Kim, S. H., Paperna, I. (1992). Fine structure of epicytoplasmic stages of Eimeria vanasi from the gut of cichlid fish. Dis. aquat. Org. 12: 191-197

Lom, J., Steinhagen, D., Körting, W., Dykova, I. (1991). Oocyst formation in the coccidian parasite Goussia carpelli. Dis aquat. Org. 10: 203-209

McDowell, E. M. (1978). Fixation and processing. In: Trump 
B. F. Jones, R. T (eds.) Diagnostic electron microscopy. 1. John Wiley and Sons, New York

Morrison, C. M., Hawkins, W E. (1984). Coccidians in the liver and testis of the herring Clupea harengus L. Can. J Zool. 62: 480-493

Morrison, C. M., Leger, J. P., Morrison, C. A. (1993). Light and electron microscopic study of the pathology and merogony of Goussia gadi (Apicomplexa: Coccidia) in the swimbladder wall of haddock Melanogrammus aeglefinus. Dis. aquat. Org. 17: 113-125

Morrison, C. M., McClelland, G., Cornick, J., Marcogliese, D. (1986). Parasites and diseases of some marine finfish off Nova Scotia. Can. Tech. Rep. Fish. Aquat. Sci. 1424

Odense, P. H., Logan, V. H. (1976). Prevalence and morphology of Eimeria gadi (Fiebiger, 1913) in the haddock. J. Protozool. 23: 564-571

Paterson, W. B., Desser, S. S. (1981a). An ultrastructural study of microgametogenesis and the microgamete in Eimeria iroquoina Molnar and Fernando, 1974, in experimentally infected fathead minnows (Pimephales promelas, Cyprinidae). J. Parasitol. 67: 314-324

Paterson, W. B., Desser, S. S. (1981b). Ultrastructure of macrogametogenesis, macrogametes and young oocysts of

Responsible Subject Editor: W. Körting, Hannover, Germany
Eimeriairoquoina Molnar \& Fernando, 1974, in experimentally infected fathead rninnows (Pimephales promelas, Cyprinidae). J. Parasitol. 67: 496-504

Paterson, W. B., Desser, S. S. (1984). Ultrastructural observations on fertilization and sporulation in Goussia iroquona (Molnar and Fernando, 1974) in experimentally infected fathead minnows (Pimephales promelas, Cyprinidae). J. Parasitol. 70: 703-711

Scholtyseck, E. (1973). Ultrastructure. In: Hammond, D. M., Long, P. L. (eds.) The coccidia. University Park Press, Baltimore, p. 81-144

Steinhagen, D. (1991). Ultrastructural observations on merogonic and gamogonic stages of Goussia carpelli (Apicomplexa, Coccidia) in experimentally infected common carp Cyprinus carpio. Eur. J. Protistol. 27: $71-78$

Steinhagen, D., Lukes, J., Körting, W. (1990). Ultrastructural observations on gamogonic stages of Goussia subepithelialis (Apicomplexa, Coccidia) from common carp Cyprinus carpio. Dis. aquat. Org. 9: 31-36

Upton, S. J., Reduker, D. W., Current, W. L., Duszynski, D. W. (1984). Taxonomy of North American fish Eimeriidae. NOAA Tech. Rep. NMFS 11, Washington, DC

Manuscript first received: March 12, 1993

Revised version accepted: July 5, 1993 